\title{
The immunohistochemical localization of the vascular endothelial growth factor and its receptors in the testes and epididymis of the rabbit*
}

\author{
Nilgün ANTEPLí ${ }^{1}$, Feyzullah BEYAZ ${ }^{2}$ \\ ${ }^{1}$ Institute of Food, Agriculture and Livestock; ${ }^{2}$ Erciyes University, Faculty of Veterinary Medicine, Department of Histology and \\ Embryology, Kayseri, Turkey.
}

\begin{abstract}
Summary: This study was aimed at demonstrating the immunohistochemical expression of VEGF and its receptors flt- 1 and flk-1 in the testes and epididymis of the rabbit and at investigating the potential role of these molecules in testicular and epididymal physiology. The testes and epididymis of 15 male adult New Zealand rabbits constituted the material of the study. The streptavidinbiotin complex (ABC) immunohistochemical technique was used to determine the localization of VEGF and its receptors flt-1 and flk1 in the testes and epididymis. In the testes, immunoreactivity for VEGF and its receptors flt- 1 and flk-1 was observed in the Sertoli cells and spermatogonia in the seminiferous tubules throughout all of the spermatogenic stages from I to VIII and in the Leydig cells of the interstitium. Furthermore, immunoreactivity was also observed in the acrosome of the spermatids in seminiferous tubules for VEGF at stages V, VI, VII and VIII and in the acrosome of the spermatids at stages VII and VIII and the blood vessels of the interstitium for flk-1. Positive immunoreactivity, ranging from strong to weak, was detected for VEGF, flt-1 and flk-1 in the cytoplasm of the principal, apical, basal and clear cells of the epithelium lining the epididymal initial segment and the caput, corpus and cauda epididymidis. The specific localization of the VEGF protein and its receptors flt- 1 and flk- 1 in the testes of the rabbit suggests that these molecules could have a functional role in several processes, including spermatogonial differentiation, spermiogenesis, acrosome development in spermatids, steroidogenesis in Leydig cells, epididymal sperm maturation, and the maintenance of the bloodepididymis barrier.
\end{abstract}

Keywords: Epididymis, rabbit, testis, VEGF, VEGF receptors.

\section{Tavşan testis ve epididimislerinde vasküler endoteliyal büyüme faktörü ve reseptörlerinin immunohistokimyasal lokalizasyonu}

Özet: Bu çalışmanın amacı, VEGF ve reseptörleri flt-1 ile flk-1'in tavşan testis ve epididimisindeki immunohistokimyasal ekspresyonlarını belirlemek ve bu moleküllerin testis ve epididimis fizyolojisindeki potansiyel rollerini araştırmaktır. Çalışmada materyal olarak, 15 adet sağlıklı, erkek Yeni Zellanda tavşanından elde edilen testis ve epididimisler kullanıldı. VEGF ve reseptörleri flt-1 ile flk-1'in testis ve epididimisdeki lokalizasyonlarının belirlenmesi amaciyla streptavidin biotin kompleks (ABC) immunohistokimyasal yöntemi kullanıldı. Testiste, I'den VIII'e kadarki tüm spermatojenik evrelerde seminifer tubüllerdeki Sertoli hücreleri ve spermatogonialarda ve intersitisyumda Leydig hücrelerinde VEGF ve reseptörleri flt-1 ile flk-1 için immunreaktivite gözlendi. Buna ilaveten, seminifer tubüllerde V., VI., VII. ve VIII. evrelerde VEGF için, VII. ve VIII. spermatojenik evrelerde ise flk1 için spermatidlerin akrozomlarında ve intersitisyumda kan damarlarında immunreaktivite belirlendi. Epididimiste, başlangıç segmenti, kaput, korpus ve kauda epididimidis epitelindeki prensipal, apikal ve bazal hücreleri ile clear hücrelerinin sitoplazmalarında zayıftan şiddetliye değişen derecelerde VEGF, flt-1 ve flk-1 için pozitif immunreaktivite tespit edildi. VEGF proteini ve reseptörleri flt-1 ve flk-1'in tavşan testislerindeki spesifik lokalizasyonları, bu moleküllerin spermatogonial farklılaşma, spermiyogenezis, spermatidlerde akrozom gelişimi ve Leydig hücrelerinde steroidiogeneziste, ayrıca epididimiste sperm olgunlaşması ve kan-epididimis bariyerine katkı sağlama gibi fonksiyonel görevleri olabileceğini göstermektedir.

Anahtar sözcükler: Epididimis, tavşan, testis, VEGF, VEGF reseptörleri.

\section{Introduction}

The testes are the principal functional organs of the male reproductive system and are responsible for gametogenesis and steroidogenesis $(6,20)$. On the basis of its histological and cytochemical features, the epididymis is divided into four distinct regions, namely, the epididymal initial segment, caput epididymidis, corpus epididymidis, and cauda epididymidis $(5,8,12,23)$. The

\footnotetext{
* This study is a summary of the Master's thesis of the first author.
} 
ductus epididymidis is lined by a pseudostratified columnar epithelium, which is composed of columnar principal cells with stereocilia and basal cells connected to the basal lamina, and also contains apical, clear and halo cells, all which are specifically localized to this region (5).

The vascular endothelial growth factor (VEGF, VEGF-A or VPF) is a $40-\mathrm{kDa}$ heparin-dependent, homodimeric glycoprotein $(5,7,15,16,18)$. VEGF was first named as the vascular permeability factor (VPF), and was later described as an angiogenic factor involved in the regulation of the proliferation, migration and vitality of endothelial cells $(2,4,9)$. VEGF, which is known to be highly distributed in embryonic tissues, has also been shown to exist in adult tissues, but its functions in adult tissues have not been fully elucidated yet $(10,11,13)$. VEGF shows activity by means of its receptors flt- 1 and flk-1. The activation of the VEGF receptors phosphorylates several intracellular signalling proteins, including among others the activator proteins phosphoinositol-3 kinase, phospholipase $\mathrm{C}$ and ras GTPase, and thereby, leads to the proliferation, migration and differentiation of endothelial cells $(9,15,16,21,22)$. On the contrary to adult females, active angiogenesis does not take place in the testes of adult males $(13,21)$. Despite this fact, reports indicate that high levels of VEGF are produced in the testes. Although the role of VEGF in embryonic development and pathological processes such as tumour formation is well understood, its role in the adult genital system has not been fully elucidated yet $(2$, $3,4)$. Nonetheless, to date, the expression and localization of VEGF and its receptors in the testes and epididymis have been demonstrated in humans $(7,8)$, rats $(1,23)$, mice (12), roe-deer (19) and some wild animals (17) using various methods. In view of the results of these studies, it is considered that VEGF could have an important role in spermatogenesis, spermiogenesis, and steroidogenesis in the testicular tissue $(1,7,17,19)$. On the other hand, to the authors' knowledge, there is no previous study on the presence or localization of the VEGF protein and the flt-1 and flk-1 receptors this protein binds to in the testes and epididymis of the rabbit. This study was based on the hypothesis that, similar to the case in humans $(7,8)$ and some other animal species $(1,12,17,19)$, VEGF and its receptors flt-1 and flk-1 may have an important role in spermatogenesis, spermiogenesis, steroidogenesis and sperm maturation in the testes and epididymis of the rabbit. In this context, this study was aimed at demonstrating the presence and immunohistochemical expression of the VEGF protein and its receptors, flt-1 and flk-1, in the rabbit testes and epididymis by means of the streptavidin-biotin complex (ABC) immunohistochemical technique, and investigating the potential role of these molecules in the physiology of the testes and epididymis.

\section{Materials and Methods}

Animals: Fifteen healthy male adult New Zealand rabbits were used in this study. The animals were provided with standard laboratory feed and fresh drinking water, and were housed at a room temperature range of $23 \pm 2{ }^{\circ} \mathrm{C}$. The rabbits were euthanized by the intravenous administration of $0.1 \mathrm{ml} / \mathrm{kg}$ of sodium pentobarbital. Subsequently, 30 tissue samples were taken from the right and left testes and epididymis of the animals for immunohistochemical examination. The animals used in this study were euthanized with the approval of the Ethics Board of Erciyes University, Faculty of Veterinary Medicine (Date of meeting: 10.04.2007, Decision No: 13/21).

Tissue processing and immunostaining: The tissue samples were first fixed in Bouin's solution for 12 hours and later passed through a series of graded alcohols, methyl benzoate and benzene. After being embedded in paraffin, $5 \mu \mathrm{m}$-thick sections were cut from each block. With an aim to determine the localization of VEGF, flt-1 and flk-1 in the testes and epididymis, the sections were employed the streptavidin-biotin complex (ABC) technique for immunohistochemical examination. To block endogenous peroxidase activity, the sections were treated with $3 \%$ of hydrogen peroxide in methanol for 20 minutes. Subsequently, for antigenic recovery, the tissue sections were immersed in a citrate buffer solution at 90 ${ }^{0} \mathrm{C}$ for 20 minutes. Next, in order to prevent non-specific binding, the sections were treated with a blocking solution (Ultra V Block, Thermo Fisher) for 5 minutes. Later the sections were incubated with the monoclonal mouse antiVEGF (1:400, clone: Ab-3(JH121), Cat.No: MS-350, Thermo Sci.), monoclonal mouse anti-VEGFR1 (1:50, clone: Flt-1/EWC, Cat.No: 9540, Abcam) and monoclonal mouse anti-VEGFR2 (1:50, clone: KDR, Cat. No: 10973, Abcam) primary antibodies for 1 hour. Subsequently, the sections were treated with biotinylated anti-mouse secondary antibody (Labvision, Ultravision kit, TM-125HL) for 15 minutes and with avidin-peroxidase solution (Labvision, Ultravision kit, TM-125-HL) for another 15 minutes. In order to visualise the antigen-antibody reaction, the sections were first applied the DAB chromogen (Invitrogen) for 5-10 minutes and then Gill's haematoxylin for 5 minutes for background staining. All stainings were performed at room temperature in a humidity chamber, and washes were performed using PBS. Tissues from the skin and intestines of the rabbit were used as the positive control. For negative control purposes, primary antibodies were replaced by PBS and the rest of the staining was performed as in the normal procedure. The tissue sections were examined by conventional light microscopy (BX51; Olympus, Tokyo, Japan) and were evaluated for VEGF, flt-1 and flk-1 
immunoreactivity. The sections were photographed with a digital camera (Olympus DP72). The results of the staining procedures were assessed semi-quantitatively. When examined under a light microscope, the absence of stained cells at high magnification (X40) was considered as no reaction (-). On the other hand, reactions observed only at high magnification (X40) were considered to be weak (+), those easily observed at low magnification $(10 \mathrm{X})$ were considered to be of moderate intensity $(++)$, and those presenting with a distinct appearance at low magnification $(10 \mathrm{X})$ were considered to be strong (+++).

\section{Results}

Testes: Immunostainings performed for VEGF demonstrated the presence of a granular type of VEGFpositive immunoreaction of varying intensity, ranging from strong to weak, throughout the eight stages of spermatogenic development in the cytoplasm of the Sertoli cells and spermatogonia in the seminiferous tubules (Figures 1A-H). At stages V, VI, VII and VIII of spermatogenic development, a strong positive immunoreaction was determined for VEGF in the acrosomes of the new generation of spermatids (Figures 1E-H). While immunoreactions were not observed in spermatocytes at any of the spermatogenic stages, a strong VEGF-positive immunoreaction was detected in the cytoplasm of the Leydig cells and the blood vessels in the interstitial tissue throughout spermatogenic development (Figures 1A-H).

Immunostainings performed for flt-1 demonstrated the presence of a granular type of flt-1-positive immunoreaction of varying intensity, ranging from moderate to strong, throughout the eight stages of spermatogenic development in the Sertoli cells and spermatogonia in the seminiferous tubules. While no reaction was detected in the spermatocytes and spermatids, in the interstitial tissue a moderate flt-1immunoreaction was observed in the Leydig cells and blood vessels (Figures 2A-H).

Similar to those performed for flt-1, immunostainings performed for flk-1 revealed the presence of a strong flk-1-positive immunoreaction throughout the eight stages of spermatogenic development in the cytoplasm of the Sertoli cells and spermatogonia in the seminiferous tubules. Furthermore, at stages VII and VIII, similar to the results obtained with the immunostainings performed for VEGF, a strong flk-1positive reaction was detected in the acrosome of the spermatids. While immunostaining was not observed in the spermatocytes at any of the spermatogenic development stages, in the interstitial tissue, a strong flk- 1-positive immunoreaction was observed in the Leydig cells and blood vessels (Figures 3A-H) (Table 1).

Epididymis: Immunostainings for VEGF showed the presence of a granular type of immunoreaction in the apical and basal cytoplasm of the principal cells of the epithelium lining the epididymal initial segment, and a strong immunoreaction in the cytoplasm of the apical cells and some basal cells (Figure 4A). Furthermore, while a granular immunoreaction was observed in the apical and basal cytoplasm of the principal cells, a dense immunoreaction was detected in the cytoplasm of some of the basal cells of the epithelium lining the caput (Figure 4D), corpus (Figure 4G) and cauda epididymidis (Figure $4 J$ ). Immunoreactivity was observed for VEGF in the perinuclear cytoplasm of the clear cells in the epithelium lining the cauda epididymidis. The blood vessels in the interstitium displayed a moderate reaction.

Immunostainings for flt-1 demonstrated granular immunoreactions, ranging from weak to strong, in the apical and basal cytoplasm of the principal cells, and a denser immunostaining in the cytoplasm of some of the principal and basal cells of the epithelium lining the initial segment of the epididymis (Figure 4B). In the epithelium lining the caput (Figure 4E), corpus (Figure 4H) and cauda epididymidis (Figure $4 \mathrm{~K}$ ), while a granular type of immunoreactivity was observed in the apical and basal cytoplasm of the principal cells, a dense immunoreactivity was observed in the cytoplasm of some of the basal cells. Furthermore, the blood vessels also displayed positive reaction. Immunoreactivity was detected for flt- 1 in the apical cytoplasm of the clear cells of the epithelium lining the cauda epididymidis. An immunoreaction of moderate intensity was observed in the blood vessels of the interstitium.

Immunostainings performed for flk-1 demonstrated granular positive immunoreactions, ranging from moderate to strong, in the apical and basal cytoplasm of the principal cells of the epithelium lining the initial segment of the epididymis, and it was noted that the immunostaining was denser in the cytoplasm of some apical cells and basal cells (Figure 4C). Immunoreactivity was granular in the apical and basal cytoplasm of the principal cells lining the caput (Figure 4F), corpus (Figure 4I) and cauda epididymidis (Figure 4L), and was dense in the cytoplasm of some of the basal cells. A rather dense immunoreactivity was observed in particular in the lateral membranes of the principal cells. Immunoreactivity for flk-1 was detected in the apical and basal cytoplasm of the clear cells in the epithelium lining the cauda epididymidis. In the interstitium, the blood vessels displayed a rather intense reaction (Figures 4C, F, I and L) (Table 2). 

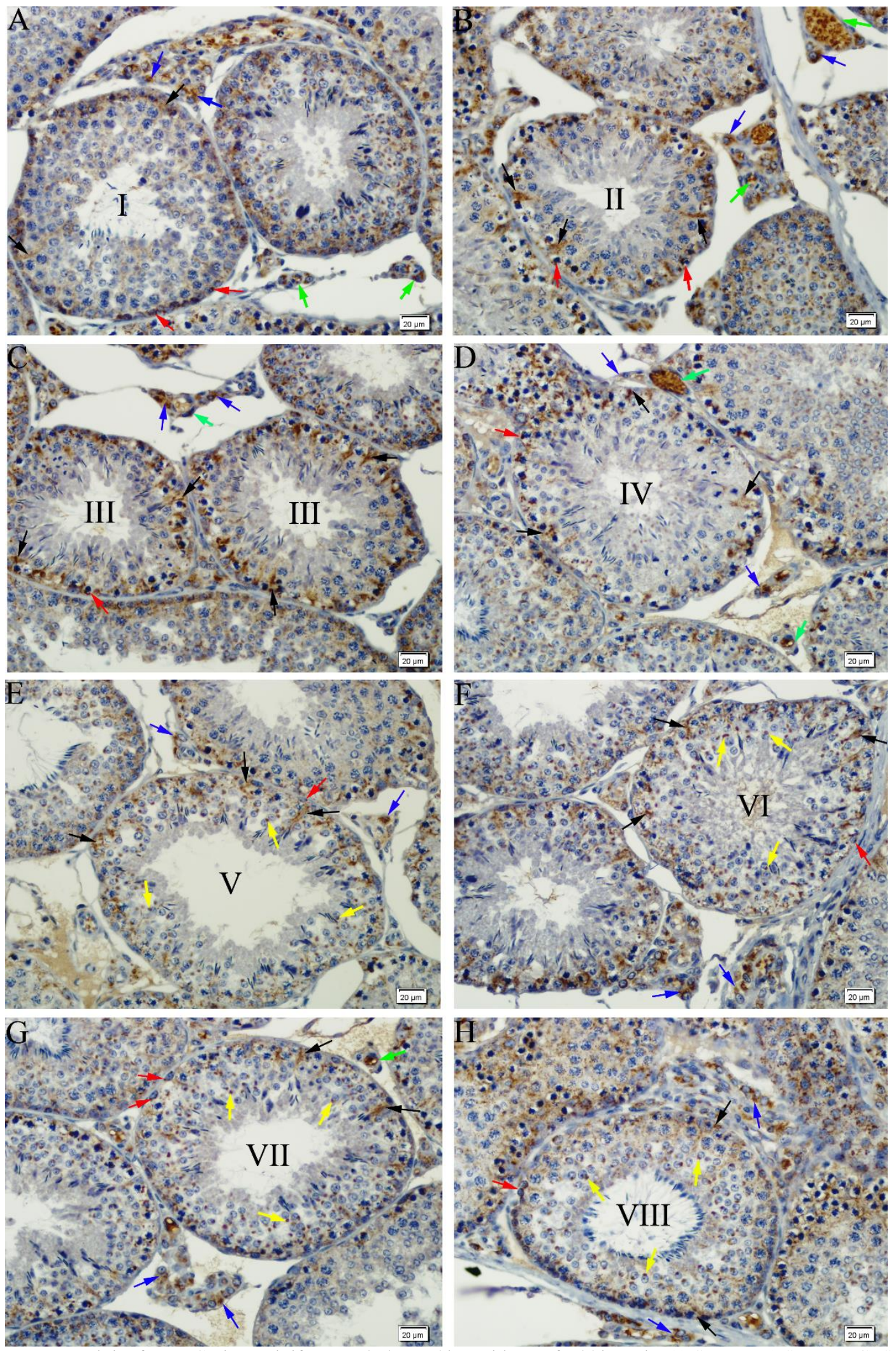

Figure 1. Immunoreactivity for VEGF in seminiferous tubules and intersititum of rabbit testis. A) Stage I, B) Stage II, C) Stage III, D) Stage IV, E) Stage V, F) Stage VI, G) Stage VII, H) Stage VIII. VEGF positive Sertoli cells (black arrows), spermatogonia (red arrows), spermatids (yellow arrows), Leydig cells (blue arrows) and blood vessels (green arrows). Immunohistochemical staining, DAB, Bar $20 \mu \mathrm{m}$.

Şekil 1. Tavşan testisinde seminifer tubüllerde ve intersitisyumda VEGF immunreaktivitesi. A) Safha I, B) Safha II, C) Safha III, D) Safha IV, E) Safha V, F) Safha VI, G) Safha VII, H) Safha VIII. VEGF pozitif Sertoli hücreleri (siyah oklar), spermatogonialar (kırmız1 oklar), spermatidler (sarı oklar), Leydig hücreleri (mavi oklar) ve kan damarları (yeşil oklar). Immunohistokimyasal boyama, DAB, Bar $20 \mu \mathrm{m}$. 

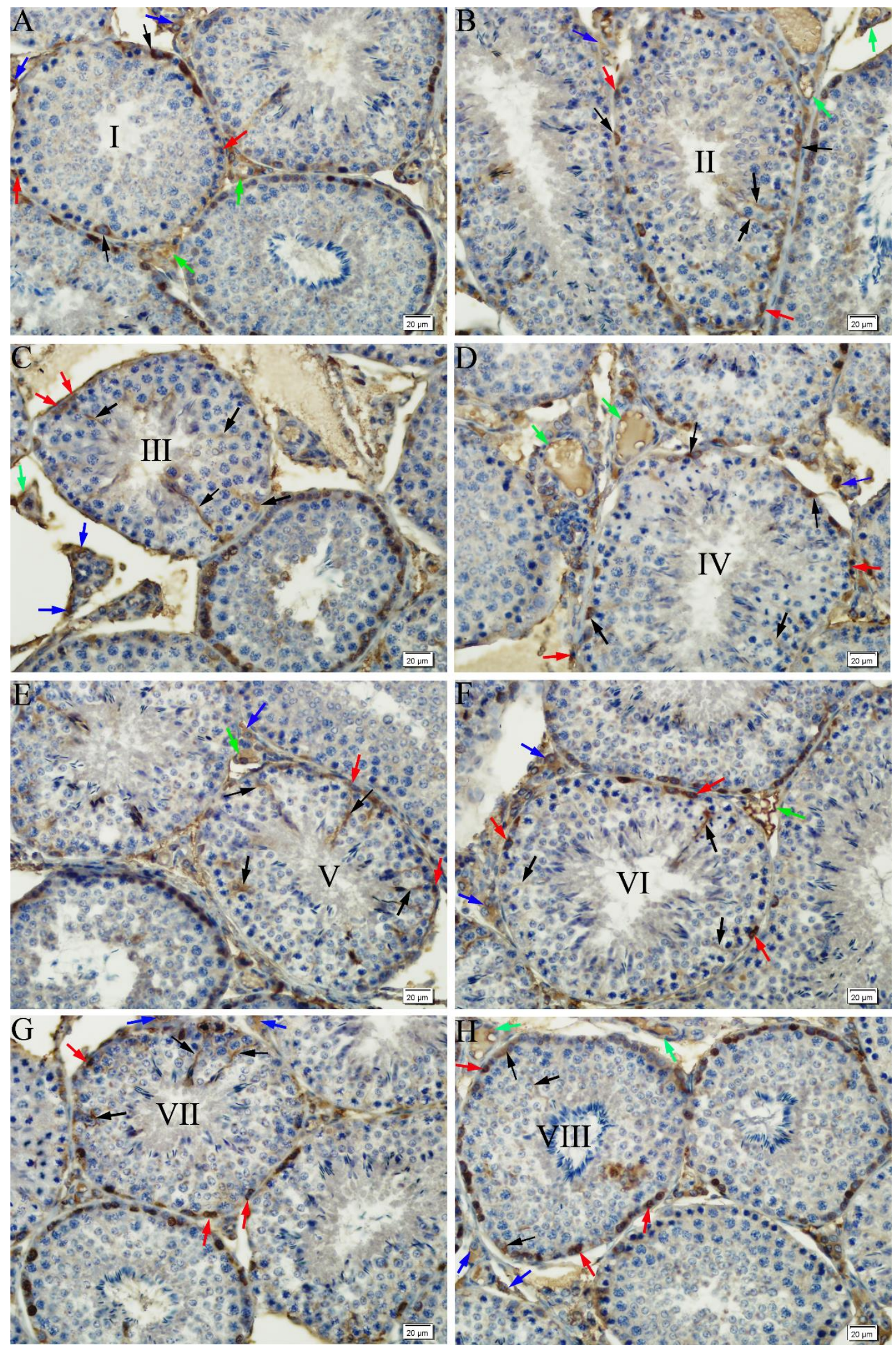

Figure 2. Immunoreactivity for flt-1 in seminiferous tubules and intersititum of rabbit testis. A) Stage I, B) Stage II, C) Stage III, D) Stage IV, E) Stage V, F) Stage VI, G) Stage VII, H) Stage VIII. Flt-1 positive Sertoli cells (black arrows), spermatogonia (red arrows), Leydig cells (blue arrows) and blood vessels (green arrows). Immunohistochemical staining, DAB, Bar $20 \mu \mathrm{m}$.

Şekil 2. Tavşan testisinde seminifer tubüllerde ve intersitisyumda flt-1 immunreaktivitesi. A) Safha I, B) Safha II, C) Safha III, D) Safha IV, E) Safha V, F) Safha VI, G) Safha VII, H) Safha VIII. Flt-1 pozitif Sertoli hücreleri (siyah oklar), spermatogonialar (kırmızı oklar), Leydig hücreleri (mavi oklar) ve kan damarları (yeşil oklar). Immunohistokimyasal boyama, DAB, Bar $20 \mu \mathrm{m}$. 

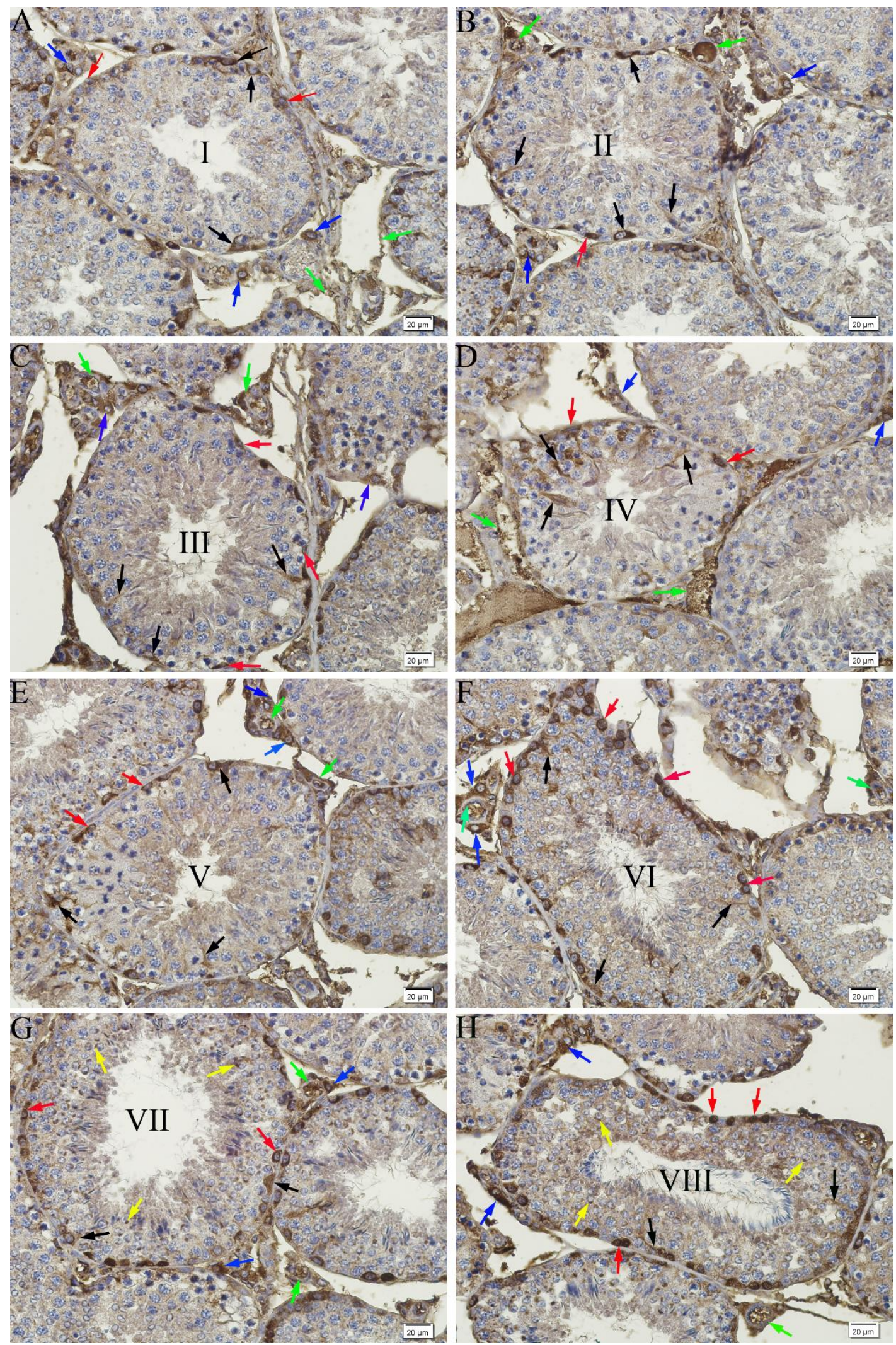

Figure 3. Immunoreactivity for flk-1 in seminiferous tubules and intersititum of rabbit testis. A) Stage I, B) Stage II, C) Stage III, D) Stage IV, E) Stage V, F) Stage VI, G) Stage VII, H) Stage VIII. Flk-1 positive Sertoli cells (black arrows), spermatogonia (red arrows), spermatids (yellow arrows), Leydig cells (blue arrows) and blood vessels (green arrows). Immunohistochemical staining, DAB, Bar $20 \mu \mathrm{m}$.

Şekil 3. Tavşan testisinde seminifer tubüllerde ve intersitisyumda flk-1 immunreaktivitesi. A) Safha I, B) Safha II, C) Safha III, D) Safha IV, E) Safha V, F) Safha VI, G) Safha VII, H) Safha VIII. Flk-1 pozitif Sertoli hücreleri (siyah oklar), spermatogonialar (kırmızı oklar), spermatidler (sarı oklar), Leydig hücreleri (mavi oklar) ve kan damarları (yeșil oklar). Immunohistokimyasal boyama, DAB, Bar $20 \mu \mathrm{m}$. 
Table 1. Immunohistochemical localization of VEGF and its receptors flt-1 and flk-1 in seminiferous epithelium and interstitium in rabbit testis.

Tablo 1. Tavşan testisinde seminifer epitel ve intersitisyumda VEGF ve reseptörler flt-1 ve flk-1'in immunohistokimyasal lokalizasyonu.

\begin{tabular}{|c|c|c|c|c|c|c|c|}
\hline \multirow[t]{2}{*}{ Stages } & \multirow[t]{2}{*}{ Reaction } & \multicolumn{4}{|c|}{ Seminiferous epithelium } & \multicolumn{2}{|c|}{ İnterstitium } \\
\hline & & Sertoli cells & Spermatogonia & Spermatocytes & Spermatids & $\mathrm{LC}$ & BV \\
\hline \multirow[t]{3}{*}{ Stage I } & VEGF & + & ++ & - & - & & \\
\hline & flt-1 & ++ & +++ & - & - & & \\
\hline & flk-1 & +++ & +++ & - & - & & \\
\hline \multirow[t]{3}{*}{ Stage II } & VEGF & + & ++ & - & - & & \\
\hline & flt-1 & ++ & +++ & - & - & & \\
\hline & flk-1 & +++ & +++ & - & - & & \\
\hline \multirow[t]{3}{*}{ Stage III } & VEGF & ++ & ++ & - & - & & \\
\hline & flt-1 & +++ & +++ & - & - & & \\
\hline & flk-1 & +++ & +++ & - & - & & \\
\hline \multirow[t]{3}{*}{ Stage IV } & VEGF & ++ & ++ & - & - & +++ & ++ \\
\hline & flt-1 & +++ & +++ & - & - & ++ & ++ \\
\hline & flk-1 & +++ & +++ & - & - & +++ & ++ \\
\hline \multirow[t]{3}{*}{ Stage V } & VEGF & +++ & ++ & - & ++ & & \\
\hline & flt-1 & +++ & +++ & - & - & & \\
\hline & flk-1 & +++ & +++ & - & - & & \\
\hline \multirow[t]{3}{*}{ Stage VI } & VEGF & +++ & ++ & - & ++ & & \\
\hline & flt-1 & +++ & +++ & - & - & & \\
\hline & flk-1 & +++ & +++ & - & - & & \\
\hline \multirow[t]{3}{*}{ Stage VII } & VEGF & +++ & ++ & - & ++ & & \\
\hline & flt-1 & +++ & +++ & - & - & & \\
\hline & flk-1 & +++ & +++ & - & ++ & & \\
\hline \multirow[t]{3}{*}{ Stage VIII } & VEGF & +++ & ++ & - & ++ & & \\
\hline & flt-1 & +++ & +++ & - & - & & \\
\hline & flk-1 & +++ & +++ & - & ++ & & \\
\hline
\end{tabular}

Abbreviations: VEGF; Vascular endothelial growth factor, LC; Leydig cells, BV; Blood vessels

Immunohistochemical staining in the testis samples were semiquantitatively evaluated using an intensity score that reflected the intensity of positive staining in the cell cytoplasms. The intensity score was recorded as (-) or negative (no staining of any cells even at high magnificiation), (+) or weak (only visible at high magnificiation), (++) or moderate (readily visible at low magnification), and $(+++)$ or strongly (strikingly positive at low-power magnification).

Kısaltmalar: VEGF, Vasküler endoteliyal büyüme faktörü; LC, Leydig hücreleri; BV, Kan damarları

Testis dokularındaki immunohistokimyasal boyanma, hücre sitoplazmasındaki pozitif boyanma yoğunluğunu ortaya koyan bir yoğunluk skorlaması kullanılarak semi-kantitatif olarak değerlendirildi. Yoğunluk skoru (-) veya negatif (yüksek büyütmeler de bile hücrelerde boyanma yok), $(+)$ veya zayıf (sadece yüksek büyütmelerde görülebilir), $(++)$ veya orta (düşük büyütmelerde kolayca görülebilir), ve (+++) veya güçlü (düşük büyütmelerde çok çarpıcı bir şekilde pozitif) olarak kaydedildi. 

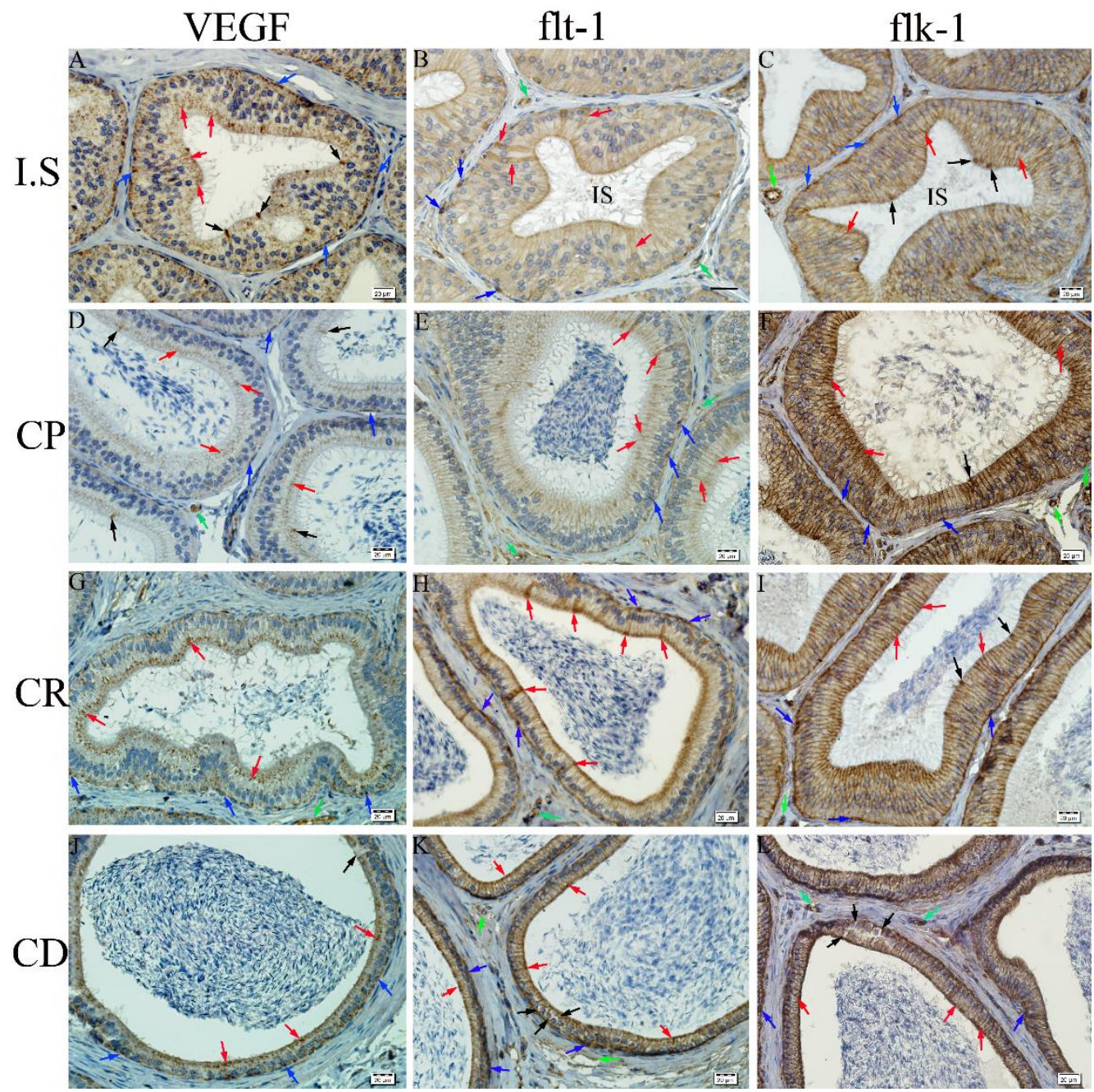

Figure 4. Immunoreactivity for VEGF (A, D, G and J), flt-1 (B, E, H and K) and flk-1 (C, F, I and L) in ductus epididymidis and intersititium of rabbit epididymis. A) At the initial segment (IS), VEGF positive principle (red arrows), apical (black arrows) and basal cells (blue arrows). B) At the initial segment (IS), immunoreactivity for flt-1 in principle (red arrows) and basal cells (blue arrows) or blood vessels (green arrows). C) At the initial segment (IS), immunoreactivity for flk-1 especially, in the lateral borders of principle cells (red arrows) and in apical (black arrows), basal cells (blue arrows) and blood vessels (green arrow). D) At the caput epididymidis (CP), VEGF positive principle (red arrows), apical (black arrows) and basal cells (blue arrows), and blood vessels (green arrow). E) At the caput epididymidis (CP), flt-1 positive principle (red arrows) and basal cells (blue arrows), and blood vessels (green arrow). F) At the caput epididymidis (CP), flk-1 positive principle (red arrows), apical (black arrows) and basal cells (blue arrows), and blood vessels (green arrow). G) At the corpus epididymidis (CR), VEGF positive principle (red arrows) and basal cells (blue arrows), and blood vessels (green arrow). H) At the corpus epididymidis (CR), immunoreactivity for flt-1 in principle (red arrows) and basal cells (blue arrows), and blood vessels (green arrow). I) At the corpus epididymidis (CR), flk-1 positive principle (red arrows), apical (black arrows) and basal cells (blue arrows), and blood vessels (green arrow). J) At the cauda epididymidis (CD), VEGF positive principle (red arrows), clear (black arrows) and basal cells (blue arrows). K) At the cauda epididymidis (CD), immunoreactivity for flt-1 in principle (red arrows), clear (black arrows) and basal cells (blue arrows), and blood vessels (green arrow). L) At the cauda epididymidis (CD), immunoreactivity for flk-1 especially, in the lateral borders of principle cells (red arrows), in clear (black arrows) and basal cells (blue arrows), and blood vessels (green arrow). Immunohistochemical staining, DAB, Bar $20 \mu \mathrm{m}$.

Şekil 4. Tavşan epididimisinde, duktus epididimidis ve intersitisyumda VEGF (A, D, G ve J), flt-1 (B, E, H ve K) ve flk-1 (C, F, I ve L) immunreaktivitesi. A) Başlangıç segmentinde (IS) VEGF pozitif prensipal (kırmızı oklar), apikal (siyah oklar) ve bazal hücreler (mavi oklar). B) Başlangıç segmentinde (IS) prensipal (kırmızı oklar) ve bazal hücreler (mavi oklar) ile kan damarlarında (yeşil oklar) flt-1 immunreaktivitesi. C) Başlangıç segmentinde (IS) prensipal hücrelerin özellikle lateral sınırlarında (kırmızı oklar), apikal (siyah oklar) ve bazal hücreler (mavi oklar) ile kan damarlarında (yeşil ok) flk-1 immun reaktivitesi. D) Kaput epididimidiste (CP) VEGF pozitif prensipal (kırmızı oklar), apikal (siyah oklar) ve bazal hücreler (mavi oklar) ile kan damarı (yeşil ok). E) Kaput epididimidiste (CP) flt-1 pozitif prensipal (kırmızı oklar), bazal hücreler (mavi oklar) ve kan damarı (yeşil ok). F) Kaput epididimidiste (CP) flk-1 pozitif prensipal (kırmızı oklar), apikal hücreler (siyah ok) ve bazal hücreler (mavi oklar) ile kan damarı (yeşil oklar). G) Korpus epididimidiste (CR) VEGF pozitif prensipal (kırmızı oklar) ve bazal hücreler (mavi oklar) ile kan damarı (yeşil ok). H) Korpus epididimidiste (CR) prensipal (kırmızı oklar) ve bazal hücreler (mavi oklar) ile kan damarında (yeşil ok) flt-1 immunreaktivitesi. I) Korpus epididimidiste (CR) flk-1 pozitif prensipal (kırmızı oklar), apikal (siyah oklar) ve bazal hücreler (mavi oklar) ile kan damarı (yeşil ok). J) Kauda epididimidiste (CD) VEGF pozitif prensipal (kırmızı oklar), clear (siyah oklar) ve bazal hücreler (mavi oklar). K) Kauda epididimidiste (CD) prensipal hücrelerin özellikle lateral kenarlarında (kırmızı oklar), clear (siyah oklar) ve bazal hücreler (mavi oklar) ile vasküler yapılarda (yeşil oklar) flt-1 immunreaktivitesi. L) Kauda epididimidiste (CD) prensipal (kırmızı oklar), clear (siyah oklar) ve bazal hücreler (mavi oklar) ile vasküler yapılarda (yeşil oklar) flk-1 immunreaktivitesi. Immunohistokimyasal boyama, DAB, Bar $20 \mu \mathrm{m}$. 
Table 2. Immunohistochemical localization of VEGF and its receptors flt-1 and flk-1 in rabbit epididymis. Tablo 2. Tavşan epididimisinde VEGF ve reseptörler flt-1 ve flk-1'in immunohistokimyasal lokalizasyonu.

\begin{tabular}{|c|c|c|c|c|c|c|c|c|}
\hline \multirow[t]{2}{*}{ Reaction } & \multirow[t]{2}{*}{ Region } & \multicolumn{5}{|c|}{ Epididymal epithelium } & \multicolumn{2}{|c|}{ Interstitium } \\
\hline & & $\mathrm{PC}$ & $\mathrm{AC}$ & $\mathrm{BC}$ & $\mathrm{CC}$ & $\mathrm{HC}$ & $\mathrm{BV}$ & PMC \\
\hline \multirow[t]{4}{*}{ VEGF } & IS & ++ & ++ & ++ & - & - & + & - \\
\hline & Caput & ++ & + & ++ & - & - & + & - \\
\hline & Corpus & ++ & - & ++ & - & - & + & - \\
\hline & Cauda & ++ & - & ++ & + & - & + & - \\
\hline \multirow[t]{4}{*}{ flt-1 } & IS & ++ & - & ++ & - & - & + & - \\
\hline & Caput & ++ & - & ++ & - & - & + & - \\
\hline & Corpus & +++ & - & ++ & - & - & + & - \\
\hline & Cauda & +++ & - & ++ & ++ & - & + & - \\
\hline \multirow[t]{4}{*}{ flk-1 } & IS & +++ & ++ & +++ & - & - & ++ & - \\
\hline & Caput & +++ & + & +++ & - & - & ++ & - \\
\hline & Corpus & +++ & + & +++ & - & - & ++ & - \\
\hline & Cauda & +++ & - & +++ & ++ & - & ++ & - \\
\hline
\end{tabular}

Abbreviations: VEGF; Vascular endothelial growth factor, PC; Principle cells, AC; Apical cells, BC; Basal cells, CC; Clear cells, HC; Halo cells, BV; Blood vessels, PMC; Peritubular muscle coat.

Immunohistochemical staining in the epididymis samples were semiquantitatively evaluated using an intensity score that reflected the intensity of positive staining in the cell cytoplasms. The intensity score was recorded as (-) or negative (no staining of any cells even at high magnificiation), (+) or weak (only visible at high magnificiation), (++) or moderate (readily visible at low magnification), and $(+++)$ or strongly (strikingly positive at low-power magnification).

Kısaltmalar: VEGF; Vasküler endoteliyal büyüme faktörü, PC; Prensipal hücreler, AC; Apikal cells, BC; Bazal hücreler, CC; Clear hücreleri, HC; Halo hücreleri, BV; Kan damarları, PMC; Peritubüler kas katmanı.

Epididimis dokularındaki immunohistokimyasal boyanma, hücre sitoplazmasındaki pozitif boyanma yoğunluğunu ortaya koyan bir yoğunluk skorlaması kullanılarak semi-kantitatif olarak değerlendirildi. Yoğunluk skoru (-) veya negatif (yüksek büyütmeler de bile hücrelerde boyanma yok), (+) veya zayıf (sadece yüksek büyütmelerde görülebilir), $(++)$ veya orta (düşük büyütmelerde kolayca görülebilir) ve (+++) veya güçlü (düşük büyütmelerde çok çarpıcı bir şekilde pozitif) olarak kaydedildi.

\section{Discussion and Conclusion}

VEGF is an angiogenic factor, which is involved in the regulation of the proliferation, migration and viability of endothelial cells $(2,13,21,22)$. VEGF is found in almost all tissues in adults and shows its effects by means of the flt-1 and flk-1 receptors found on the target cells $(10,11,15,22,26)$. VEGF makes a major contribution to the reproductive functions of females by supporting the vascular changes that occur during the menstrual cycle and the development of the ovarian follicles $(3,10)$. On the contrary to the genital system of the adult female, the testes of the adult male lack an active angiogenesis, yet very high levels of VEGF are known to be produced in the testes $(10,14,18,22)$. The presence of VEGF has been reported in the Sertoli and Leydig cells and vascular structures of the testes in humans and several animal species, and it is considered that VEGF may have an important role in spermatogenesis, spermiogenesis and steroidogenesis in the testes $(1,7,12,19)$. In view of the research of Swierstra and Foote (20) on rabbit testes, in the present study, basic criteria, including the shape of the nucleus in the spermatids, the localization of the spermatids and spermatozoa according to the basal membrane, the presence of mitotic figures, and the release of spermatozoa into the lumen of the seminiferous tubules, the spermatogenic cycle in these tubules was identified on the basis of eight stages, and immunohistochemical evaluations were performed accordingly. Furthermore, the presence and localization of VEGF and its receptors flt-1 and flk-1 in the rabbit testes and epididymis were demonstrated for the first time in the present study by means of the strept-avidin-biotin complex (ABC) immunohistochemical technique at light microscopic level.

Ergün et al. (7) demonstrated the presence of a positive immunoreaction for both VEGF and its receptors flt-1 and flk-1 in the cytoplasm of the Sertoli and Leydig cells in human testes. Ai et al. (1) reported the presence of VEGF immunoreactivity in the cytoplasm of spermatogenic germ cells, the developing acrosome of spermatids, and Sertoli and Leydig cells, and the presence of flt-1 immunoreactivity in only the Leydig cells and the developing acrosome of spermatids in rat testes. In agreement with Ai et al. (1), Zhang et al. (23) reported to have observed VEGF immunopositive particles in the Sertoli and Leydig cells and the acrosome of spermatids in 
the rat testes (23). In their study on mouse testes, while Nalbandian et al. (12) detected VEGF immunoreactivity in the cytoplasm of the Sertoli cells, they reported a negative reaction for flt- 1 and flk-1 in the same cells. These researchers also reported that while flk-1 was localized to the cytoplasm of the spermatogonia, flt- 1 was localized to the acrosomal region of the spermatids (12). Schön et al. (19) determined that, in roe-deer testes, while positive VEGF immunoreactivity was present in the spermatogonia, spermatocytes and Leydig cells, immunostainings for flt-1 were observed in spermatids and blood vessels, and immunostainings for flk-1 were observed in only the Sertoli cells. In their research on the testes of various wild animals, Reddy et al. (17) detected that, VEGF was generally expressed in the Sertoli, Leydig and germ cells. In agreement with findings reported for humans (7), rats (1, 23), mice (12) and several wild animals (17), in the present study, a positive immunoreactivity was observed for the VEGF protein in the cytoplasm of the Sertoli cells in the rabbit testicular tissue. Furthermore, similar to results obtained for the testes of the roe-deer (19), in the present study, a positive immunoreaction for VEGF was also observed in the cytoplasm of the spermatogonia. On the contrary to the case in mice (12) and similar to the case in humans (7), rats $(1,23)$, roe-deer (19) and some wild animals (17), in the rabbit testes, a strong immunopositive reaction was detected for VEGF in the Leydig cells. Furthermore, in agreement with previous reports for rats $(1,23)$ and mice (12), the present study demonstrated VEGF immunoreactivity in the acrosome of the spermatids at stages V, VI, VII, and VIII of spermatogenic development in the rabbit testes. Similar to findings obtained for the human testes (7), in this study, a positive immunoreaction was observed for flt-1 in the Sertoli and Leydig cells in rabbit testes. On the contrary to findings obtained for the testes of rats $(1,23)$ and mice (12), no positive immunoreaction was observed for flt- 1 in the acrosome of the spermatids in rabbit testes. Whereas, similar to the case in mouse testes (12), in the present study, an immunopositive reaction was detected for flk-1 in the spermatogonia. Furthermore, in the rabbit testes, immunopositive flk-1 reactions were detected in the Sertoli cells, Leydig cells and blood vessels in agreement with reports for the testes of humans (7) and roe-deer (19), and in the acrosome of the spermatids at stages VII and VIII of spermatogenic development similar to the case in rat $(1,23)$ and mouse (12) testes. The present study demonstrated that the VEGF protein and the receptors this molecule binds to, namely, flt- 1 and flk-1, are widely distributed in the rabbit testes. Thus, it can be suggested that VEGF shows a broad effect on the testicular tissue by binding to these receptors. The demonstration of the presence of the VEGF protein and its receptors flt- 1 and flk-1 in the Sertoli cells and spermatogonia in the rabbit testes suggested that these molecules could have an important role in spermatogenesis and the differentiation of spermatogonia. Furthermore, it is considered that these molecules could also have major functions in acrosome development in spermatids, steroidogenesis in Leydig cells, and the regulation of vascular permeability via testicular blood vessels.

Ergün et al. (8) reported to have detected a positive immunoreaction for VEGF in the basal cells of the ductus epididymidis as well as in the peritubular cells, and a negative immunoreaction for flt-1 and a positive immunoreaction for flk-1 in the vascular endothelium in the human epididymis. Ai et al. (1) and Zhang et al. (23) determined that VEGF displayed a region and cell-specific expression and localization in the ductus epididymidis of the rat. Zhang et al. (23) reported that VEGF was present in all of the epithelial cells lining the initial segment of the epididymis and that the immunoreactive particles were localized to the supranuclear region. They indicated that, apart from a few principal and basal cells, the immunopositive cells were, to a greater extent, composed of the clear cells localized to the caput, corpus and cauda epididymidis (23). In their research on the rat epididymis, Ai et al. (1) determined that while flt-1 was localized to the principal cells of the epididymal epithelium, both VEGF and flt-1 were localized to the acrosome, as well as to the neck, mid-piece and main tail segment of the spermatozoan. In the present study, similar to the case in humans (8) and rats (1), positive immunoreactions ranging from weak to strong in intensity, were observed for the VEGF protein in the epithelium lining the epididymis. Furthermore, the present study also demonstrated a positive immunoreactivity for flt-1 in the epididymal epithelium of the rabbit, similar to the epididymis of humans $(8)$ and rats $(1,23)$. The presence of the VEGF protein and its receptor, flt-1, in the rabbit epididymis suggested that VEGF could be involved in the maturation of sperm cells in the ductus epididymidis. It is known that there are tight junctions in-between neighbouring principal cells, which contribute to the formation of the blood-epididymis barrier. The blood-epididymis barrier enables the immune-protected environment required for the maturation of the sperm cells within the epididymal lumen, in isolation from antigens (5). It was also determined that, in the rabbit epididymis, both the epididymal epithelium and the blood vessels displayed a strong positive immunostaining for flk-1. The observation of a strong immunostaining for flk-1 in the lateral membranes of the principal cells suggested that this receptor could be localized to the intercellular junctions. As it is well known that intercellular junctions have an important role in the blood-epididymis barrier (5), it is considered that, in the rabbit epididymis, the VEGF 
protein could have a physiological function of contributing to the structure of the barrier, which it shows by means of its flk-1 receptor. Furthermore, positive immunoreactions, ranging from weak to strong in intensity, were observed for VEGF and its receptors flt-1 and flk-1 in the cells lining the ductus epididymidis. In view of the findings obtained in the present study, it is suggested that these cells express VEGF and its receptors flt-1 and flk-1, and that these molecules could have major roles in epididymal functions, such as sperm maturation and storage.

On the basis of all of the findings obtained in this study and the specific localization of the VEGF protein and its receptors flt- 1 and flk-1 in the rabbit testes, it could be hypothesized that these molecules not only have physiological functions in spermatogonial differentiation, spermiogenesis, acrosome development in spermatids, steroidogenesis in Leydig cells, and sperm maturation, but also contribute to the formation of the blood-epididymis barrier in the epididymis. Furthermore, it is suggested that VEGF could also show effect as a paracrine factor on the permeability of the testicular and epididymal blood vessels by means of its receptors, flt- 1 and flk-1.

\section{Acknowledgements}

This study was supported by the Erciyes University Research Fund (Project number: TSY-11-3399).

\section{References}

1. Ai QY, Tian H, Zhag J, et al. (2008): Expression of VEGF and Flt-1 in the testis, epididymis and epididymal sperm of adolescent rats. Zhonghua Nan Ke Xue, 14, 871-875.

2. Bates DO, Hillman NJ, Williams B, et al. (2002): Regulation of microvascular permeability by vascular endothelial growth factors. J Anat, 200, 581-597.

3. Bott RC, Clopton DT, Cupp AS (2008): A proposed role for VEGF isoforms in sex-specific vasculature development in the gonad. Reprod Domestic Anim, 43, 310-316.

4. Breen EC (2007): VEGF in biological control. J Cellular Biochem, 102, 1358-1367.

5. Cornwall GA (2009): New insight into epididymal biology and function. Human Reprod Update, 15, 213-227.

6. Çakır A, Bozkurt EÜ, Düzler A (2001): Tavşan, kobay ve sıçanda testisin şekli, konumu ve testis epididymis ilişkisi. Ankara Üniv Vet Fak Derg, 48, 129-132.

7. Ergün A, Kiliç N, Fiedler W, et al. (1997): Vascular endothelial growth factor and its receptors in normal human testicular tissue. Mol Cell Endocrinol, 131, 9-20.

8. Ergün S, Luttmer W, Fiedler W, et al. (1998): Functional expression and localization of vascular endothelial growth factor and its receptors in the human epididymis. Biol Reprod, 58, 160-168.
9. Ferrara N, Gerber HP, Le Couter J (2003): The biology of VEGF and its receptors. Nat Med, 9, 669-676.

10. Maharaj ASR, D'Amore PA (2007): Roles for VEGF in the adult. Microvascular Res, 74, 100-113.

11. Maharaj ASR, Saint-Geniez, Maldonado AE, et al. (2006): Vascular endothelial growth factor localization in the adult. Am J Pathol, 168, 639-648.

12. Nalbandian A, Dettin L, Dym M, et al. (2003): Expression of vascular endothelial growth factor receptors during male germ cell differentiation in the mouse. Biol Reprod, 69, 985994.

13. Nieminen T, Toivanen PI, Rintanen N, et al. (2004): The impact of the receptors binding profiles of the vascular endothelial growth factors on their angiogenic features. Biochem Biophysica Acta, 1840, 454-463.

14. Obermair A, Obruca A, Pöhl M, et al. (1999): Vascular endothelial growth factor and its receptors in male fertility. Fertil Steril, 72, 269-275.

15. Otrock ZK, Makarem JA, Shamseddine AI (2007): Vascular endothelial growth factor family of ligands and receptors: Review. Blood Cell Mol Dis, 38, 258-268.

16. Petrova TV, Makinen T, Alitalo K (1999): Signalling via vascular endothelial growth factor receptors. Exp Cell Res, 253,117-130.

17. Reddy N, Kasukurthi KB, Mahla RS, et al. (2012): Expression of vascular endothelial growth factor (VEGF) transcript and protein in the testis of several vertebrates, including endangered species. Theriogenology, 77, 608614.

18. Roy H, Bhardwaj S, Yla-Herttuala H (2006): Biology of vascular endothelial growth factors. FEBS Letters, 28792887.

19. Schön J, Blottner S, Gabler C, et al. (2010): Vascular endothelial growth factor $A$ is a putative paracrine regulator in seasonally controlled spermatogenesis: Insights from a ruminant model, the roe deer. Growth Factors, 28, 202-210.

20. Swierstra EE, Foote RH (1963): Cytology and kinetics of spermatogenesis in the rabbit. J Reprod Fertil, 5, 309-322.

21. Qui Y, Hoareau-Aveilla C, Oltean S, et al. (2009): The angiogenic isoforms of VEGF in health and disease. Biochem Soc Trans, 37, 1207-1213.

22. Veikkola T, Alitalo K (1999): VEGFs, receptors and angiogenesis. Semin Cancer Biol, 9, 211-220.

23. Zhang QY, Qui SD, Ge L (2004): Studies on expression and location of VEGF protein in rat testis and epididymis. Shi Yan Sheng Wu Xue Bao, 37, 1-8.

Geliş tarihi: 14.02.2017 / Kabul tarihi: 02.05.2017

Address for correspondence:

Associate Prof. Feyzullah BEYAZ

Erciyes University, Faculty of Veterinary Medicine,

Department of Histology and Embryology,

Kampus içi yerleşkesi, 38039 Talas, Kayseri, Turkey.

e-mail: fbeyaz@erciyes.edu.tr 